\title{
In Vitro Effects of Dopamine on Internal Thoracic Artery Graft Used in Coronary Artery Bypass Surger
}

\author{
Dopaminin Koroner Arter Bypass Cerrahisi Operasyonlarmda Kullamilan Internal Torasik \\ Arter Grefti Üzerine In Vitro Etkileri \\ Ümit HALICI ${ }^{1}$, Turan EGE ${ }^{2}$, Çetin Hakan KARADAĞ ${ }^{3}$, Enver DURAN² \\ ${ }^{1}$ Erzurum Bölge Eğitim ve Araştırma Hastanesi, Kalp Damar Cerrahisi, Erzurum \\ ${ }^{2}$ Trakya Üniversitesi Tip Fakültesi, Kalp Damar Cerrahisi Anabilim Dal, ${ }^{3}$ Farmakoloji Anabilim Dal, Edirne
}

Submitted / Başvuru tarihi: 12.01.2009 Accepted / Kabul tarihi: 28.01.2009

\begin{abstract}
Objective: The aim of this study was to investigate in vitro effects of dopamine on internal thoracic artery (ITA) graft.

Material and Methods: Between December 2003- June 2005, 32 patients (2 women and 30 men, mean age; $59.26 \pm 8.34$, range $37-75$ years old) who were subjected to coronary artery bypass grafting (CABG) operation in our clinic were enrolled in this study. ITA remnants were suspended in an isolated organ bath. Constrictor or relaxant responses to dopamine were recorded isometrically.
\end{abstract}

Results: Dopamine in the concentration range of $10^{-9}$ $\mathrm{M}-10^{-7} \mathrm{M}$ produced a mild relaxant effect on phenylephrine-precontracted ITA, and at higher concentrations than $10^{-7} \mathrm{M}$ it produced a constrictor response. Ther relaxant effect of dopamine was partially antagonized by L-NAME (nitric oxide synthase inhibitor, $10^{-6} \mathrm{M}$ ), propranolol $\left(10^{-6} \mathrm{M}\right)$, and cis-a-flupenthixol (dopaminergic receptor antagonist, $10^{-6} \mathrm{M}$ ), but not by metoclopramide $\left(\mathrm{D}_{2}\right.$-dopaminergic receptor antagonist). The constrictor effect of dopamine was partially antagonized by phentolamine, prazosin and, yohimbine.

Conclusion: It was concluded that, while dopamine produces a vasodilator response at the lower concentrations, it causes a constrictor effect on ITA at the higher concentrations. Both a $\beta$-adrenergic and a nitric oxide mediated mechanism (via $D_{1}$-dopaminergic receptor) may play a role in the relaxant effect of dopamine on ITA at the lower concentrations. Constrictor response to dopamine at the higher concentrations on ITA may be produced by the activation of $a_{1}$ - and $a_{2}$-adrenergic receptors.

Key words: Internal thoracic artery; coronary artery bypass surgery; dopamine.
Amaç: Bu çalışmanın amacı dopaminin internal torasik arter (ITA) grefti üzerine etkilerini, invitro araştırmaktır.

Gereç ve Yöntemler: Aralık 2003- Haziran 2005 tarihleri arasında kliniğimizde koroner arter bypass greft (CABG) operasyonu olan toplam 32 hasta (2'si kadın 30'u erkek, ortalama yaş; 59.256 $\pm 8, .34$, 37-75 yaşları arası) çalışmaya alındı. In vitro organ banyosunda hastaların ITA'larından arta kalan parçacıklar üzerinde dopaminin oluşturduğu kasıcı ve gevşetici yanıtlar isometrik olarak kaydedildi.

Bulgular: Dopamin $10^{-9} \mathrm{M}-10^{-7} \mathrm{M}$ konsantrasyon araIığında fenilefrinle önceden kastırılmış ITA'da hafif bir gevşeme yanıtı, sonrasında artan konsantrasyonlarında $\left(>10^{-7} \mathrm{M}\right)$ kasılma yanıtı gerçekleştirdiği gözlendi. Dopaminin gevşetici etkisinin kısmen L-NAME (nitrik oksit sentaz inhibitorü, $\left.10^{-6} \mathrm{M}\right)$, propranolol $\left(10^{-6} \mathrm{M}\right)$ ve cis-a-flupentiksol (dopaminerjik reseptör antagonisti, $10^{-6} \mathrm{M}$ ) ile kısmen azaldığı fakat metoklopramidin $\left(\mathrm{D}_{2}\right.$-dopaminerjik reseptör antagonisti) dopaminin kaynakklı gevşemeye etki yapmadığı gözlendi. Dopaminin ITA'daki kasıcı etkisi kısmen fentolamin, prazosin ve yohimbin ile antagonize edildiği gözlendi.

Sonuç: Sonuç olarak dopamin düşük konsantrasyonlarda ITA'da vazodilatasyon yanıtını oluştururken daha yüksek konsantrasyonlarda ITA'da vasokonstriksiyon yanıtını oluşturmaktadır. $\beta$-adrenerjik ve nitrik oksit aracılı mekanizma ( $D_{1}$-dopaminerjik reseptör yoluyla) dopaminin düşük konsantrasyonlarında ITA'da oluşturduğu gevşetici etkide rol alabilir. Dopaminin yüksek konsantrasyonlardaki ITA'da oluşturduğu kasıcı etki $a_{1}$ - ve $a_{2}$-adrenerjik reseptörlerin aktivasyonu ile oluşturulmaktadır.

Anahtar sözcükler: İnternal torasik arter; koroner arter bypass cerrahisi; dopamin

Correspondence (iletişim adresi): Dr. Ümit Halıcı. Erzurum Bölge Eğitim ve Araştırma Hastanesi, Kalp Damar Cerrahisi, Erzurum, Turkey. Tel: 04422325555 Fax (Faks): 04422325025 e-mail (e-posta): uhalici2003@yahoo.com

(c) Trakya Üniversitesi Tıp Fakültesi Dergisi. AVES Yayıncılık tarafından basılmıştır. Her hakkı sakııdır.

() Medical Journal of Trakya University. Published by AVES Publishing. All rights reserved. 


\section{INTRODUCTION}

Coronary artery bypass grafting (CABG) operation is widely performed to improve coronary circulation in patients who have coronary artery disease. Nowadays, CABG operations are widely performed with full arterial revascularization.On the other hand, varies veins could be used as a graft with or without arterial grafts in CABG operations, e.g., greater saphenous vein, lesser saphenous vein and cephalic vein. ${ }^{[1]}$ Internal thoracic artery (ITA) grafts are sensitive to vasoactive agents. Physiological and structural features of grafts are very important for short and long-term success of operations. It was known that approximately 30\% initial segment, $40-60 \%$ middle segment, and remaining last segment of ITA have elasticomuscular, elastic and elasticomuscular structures, respectively. Therefore, vasospasm of ITA might be occurred easily. As well, perioperative medical treatment plays a role in the development of vasospasm. To have knowledge of pharmacological properties of drugs, which are applied to the patients during perioperative period, are important to prevent vasospasm and to provide relaxation when necessary. Thereby, improving in graft flow and preventing of structural damages were provided. If medical treatment could not be appropriately performed, perioperative vasospasm may occur and long-term grafts patency decreases. As a part of medical treatment during perioperative period, dopamine is applied for frequently renoprotective $(3 \mu \mathrm{g} / \mathrm{kg} /$ $\mathrm{min})$, and rarely inotropic support $(3-10 \mu \mathrm{g} / \mathrm{kg} / \mathrm{min})$ in selected patients who underwent coronary artery bypass surgery. Dopamine may exert some important dilator or constrictor effects on ITA graft tissues. The aim of this study was to investigate in-vitro effects of dopamine on ITA strips in organ bath.

\section{MATERIALS AND METHODS}

Between December 2003-June 2005, the internal thoracic artery (ITA) remnants were obtained from 32 patients ( 2 women and 30 men, mean age; $59.26 \pm 8.34$, range; 37-75 years old) who were subjected to CABG operation in our clinic. This study had been approved by the "Local Ethics Committee" of our faculty. After having obtained informed consents, patients are enrolled in this study. No patient had diabetes mellitus. ITA was harvested as pedicle with electrocautery. Titanium clips were used to bind side branch of ITA. The artery was cut after bifurcation of ITA and distal ITA was ligated. ITA samples were taken before the papaverin application. ITA samples were putted in a cold Krebs solution, and then transferred to cardiovascular laboratory Department of Pharmacology at Trakya University Medical Faculty. The samples transferred to laboratory were cut in approximately $2 \mathrm{~mm}$ length rings. The rings were suspended between two stainless-steel L-shaped hooks in a $10 \mathrm{ml}$ organ bath filled with Krebs-Henseleit solution which had following composition $(\mathrm{mM})$ : $\mathrm{NaCl}$ : $122, \mathrm{KCl}: 5, \mathrm{CaCl}_{2}: 1.25, \mathrm{NaHCO}_{3}: 25.0, \mathrm{MgSO}_{4}: 1.2$,
$\mathrm{KH}_{2} \mathrm{PO}_{4}: 1$, glucose: 11.5 . Organ bath was maintained at $37^{\circ} \mathrm{C}$ and aerated with $95 \% \mathrm{O}_{2}+5 \% \mathrm{CO}_{2}$ ). Each preparation was fixed, using a silk thread, to an isometric force transducer (FDT 10-A, COMMAT, Turkey), which was connected to Transducer Acquisition System (COMMAT TDA-10-A, COMMAT, Turkey) and POLWIN 97 software. The preload tension was set at $2 \mathrm{~g}$ and maintained throughout the experiment. After equilibration period of 90 minutes, the vascular rings were tested for viability of vascular endothel. Substantial relaxation with acetylcholine $(\mathrm{ACh})\left(10^{-6} \mathrm{M}\right)$ in phenylephrine (phe) $\left(10^{-6}\right.$ $\mathrm{M})$ precontracted rings was accepted as an evidence of intact endothelium. Constrictor or relaxant responses of ITA remnants to dopamine were recorded isometrically.

The data were expressed as mean \pm standart error of the mean. The concentration-response curves were analysed by a computer program (Graphpad Prism 4 Demo software, San Diego, CA). Non linear regresion analysis (variable slope) was applied on dose-response graphics. Graphs were compared each other with F test. Values of $p$ less than 0.05 were considered statistical significant. This study was done in accordance with the Helsinki Declaration and it was supported by Trakya University Scientific Research Foundation.

Drugs: Acetylcholine chloride, phenylephrine hydrochloride, dopamine hydrochloride, cis- $\alpha$-flupenthixol, propranolol hydrochloride, $\mathrm{N} \omega$-nitro-L-arginine methyl ester (L-NAME) hydrochloride, metoclopramide hydrochloride, phentolamine hydrochloride, prazosin hydrochloride and yohimbine hydrochloride were purchased from Sigma.

\section{RESULTS}

At the beginning of the study, cumulative dopamine dose response experiments were performed. Cumulative dopamine concentrations from $10^{-9} \mathrm{M}$ to $10^{-1} \mathrm{M}$ were produced in organ bath, and relaxant contractile responses were recorded in precontracted with phenylephrine and in non-contracted ITA strips, respectively (Figure 1). As can be seen in figure 1, dopamine responses in ITA depend on dopamine concentrations; at the concentration range from $10^{-9} \mathrm{M}$ to $10^{-7} \mathrm{M}$ (Figure 1), dopamine causes mild relaxation in phenylephrine precontracted ITA, whereas at the concentration range from $10^{-7} \mathrm{M}$ to $10^{-3} \mathrm{M}$, dopamine produces contraction (Figure 1). In order to investigate whether relaxant effect of dopamine depends on nitric oxide released from vascular endothelium, cumulative dopamine dose response experiments were repeated in the existence of a nitric oxide synthase inhibitor, N $\omega$-nitro-L-arginine methyl ester (L-NAME) hydrochloride, at the $10^{-6} \mathrm{M}$ concentration (Figure 2). The existence of L-NAME decreased relaxant effect of dopamine indicating a NO: Nitric oxide (NO) -mediated mechanism $(\mathrm{p}<0.0001)$.

To investigate a possible role of $\beta$-adrenergic receptors in the effects of dopamine, cumulative dose respons- 
(a)

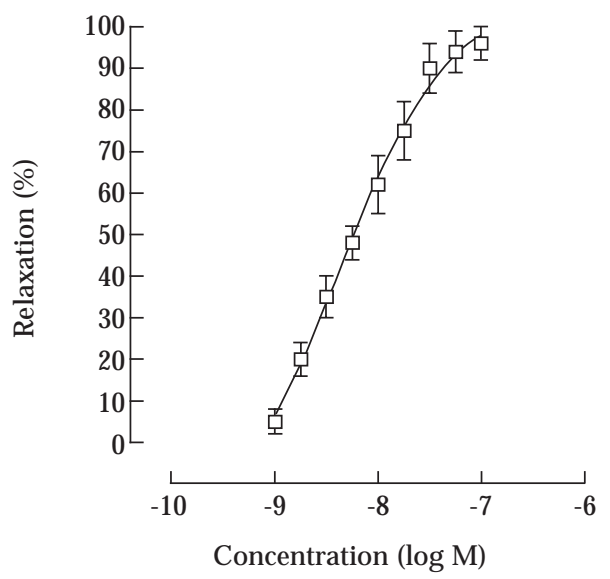

(b)

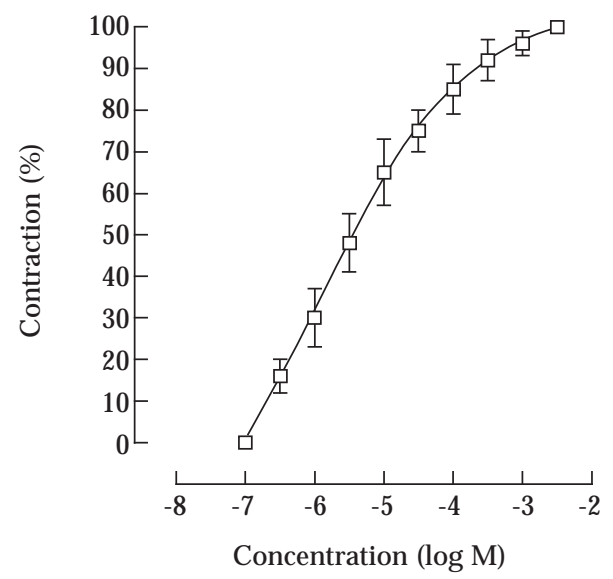

Figure 1. In vitro dopamine [ $\square]$ related vasodilation (a) and vasoconstricton (b) on ITA.

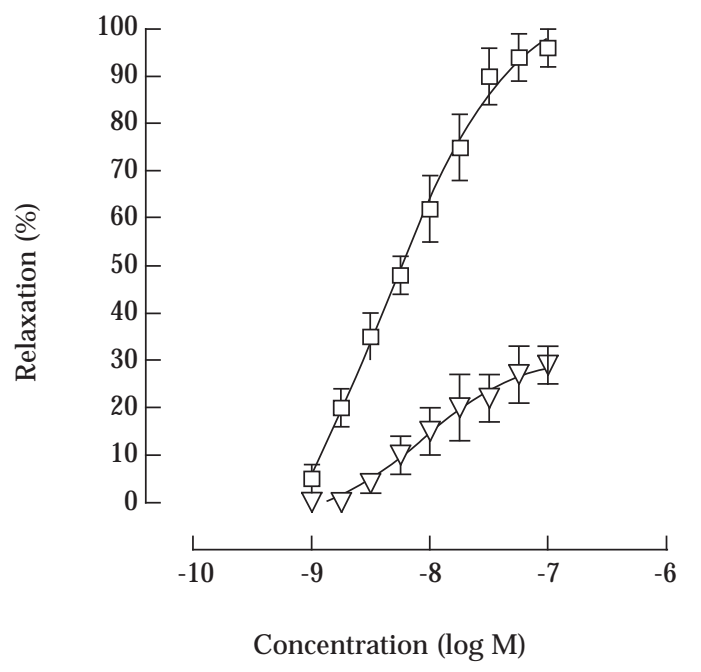

Figure 2. In vitro relaxant response to dopamine on ITA: dopamin alone $[\square]$; L-NAME $\left(10^{-6} M\right)[\nabla]$.

es were obtained in the existence of a non-selective $\beta$-adrenergic receptor blocker, propranolol hydrochloride, at the $10^{-6} \mathrm{M}$ concentration (Figure 3). Propranolol partially antagonized the relaxant effect of low dopamine concentrations $(\mathrm{p}<0.0001)$, suggesting a partial $\beta$-adrenergic receptor mediated mechanism, while it had no effect on constrictor response. The role of dopaminergic receptors in the relaxant effect of dopamine was also investigated. While dopamine $\mathrm{D}_{2}$-receptor antagonist, metoclopramide hydrochloride, at the concentration of $10^{-6} \mathrm{M}$ had no effect on relaxant response for dopamine (Figure 4), a non-selective dopaminergic receptor antagonist, cis- $\alpha$-flupenthixol, at the $10^{-6} \mathrm{M}$ concentration partially reduced the relaxant effect (Figure 5, p $<0.0001$ ), suggesting a contributing mechanism mediated by $\mathrm{D}_{1}$-dopaminergic receptor to the $\beta$-adrenergic receptor mediated mechanism.

In order to investigate the role of $\alpha$-adrenergic receptors in the contractile effect of dopamine, cumulative dose responses were obtained in the existence of nonselective $\alpha$-adrenergic receptor blocker, phentolamine hydrochloride, at the concentrations from $10^{-8} \mathrm{M}$ to $10^{-6} \mathrm{M}$ (Figure 6). Phentolamine dose dependently antagonized contractile responses of dopamine $(p<0.0001)$, showing $\alpha$-adrenergic mechanism in contractile response of dopamine in ITA. To describe $\alpha$-adrenergic receptor subtypes specific effects of dopamine, dose-response experiments were performed in the existence of $\alpha_{1}$ - and $\alpha_{2}$-specific antagonists (prazosin hydrochloride and yohimbine hydrochloride, respectively) alone and together. As can be seen in Figure 7, both prazosin $\left(10^{-6} \mathrm{M}\right)$ and yohimbine $\left(10^{-6} \mathrm{M}\right)$ antagonized contractile response to dopamine only partially, and when they were applied together to organ bath (for each antagonist $10^{-6} \mathrm{M}$ ), higher decrease in contractile response to dopamine was obtained.

\section{DISCUSSION}

Coronary artery bypass grafting is performed by autogenous grafts especially arterial grafts. In present, ITA is an arterial graft, which is mostly used. It has been known that endothelial function has a role on continuation of vascular tonus by releasing vasodilator and vasoconstrictor agents. ${ }^{[2]}$ Endothelial dysfunction exists in cardiovascular disease, ${ }^{[3]}$ and $\mathrm{NO}$ production and releasing is associated with endothelial function and vasospasm. ${ }^{[4]} \mathrm{NO}$ production and release are higher in ITA than saphenous vein, ${ }^{[3,4]}$ therefore, ITA has superior 
(a)

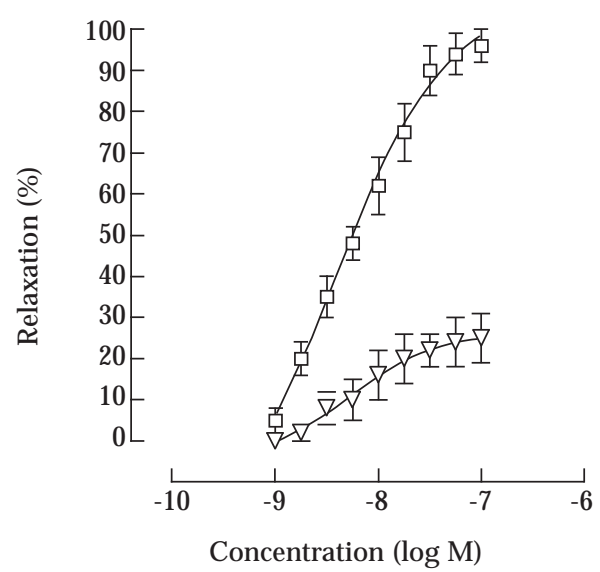

(b)

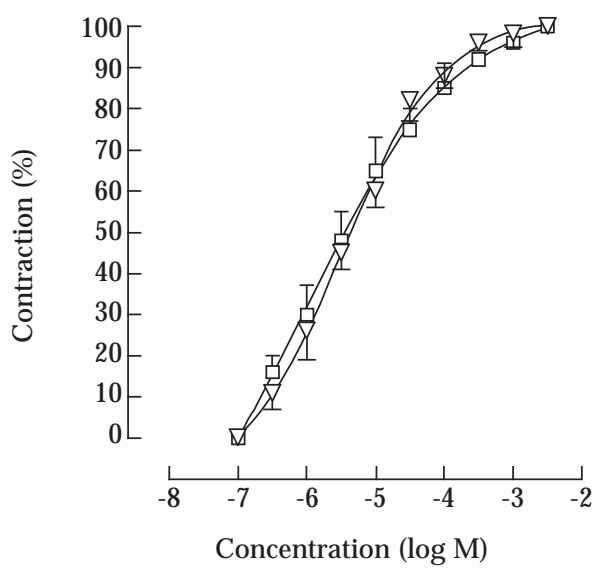

Figure 3. In vitro relaxant response to dopamine on ITA: (a) dopamine alone $[\square]$, with propranolol (10-6 M) $[\nabla]) ;(b)$ dopamine alone $[\bigcirc]$, with propranolol $\left.\left(10^{-6} \mathrm{M}\right)[\nabla]\right)$.

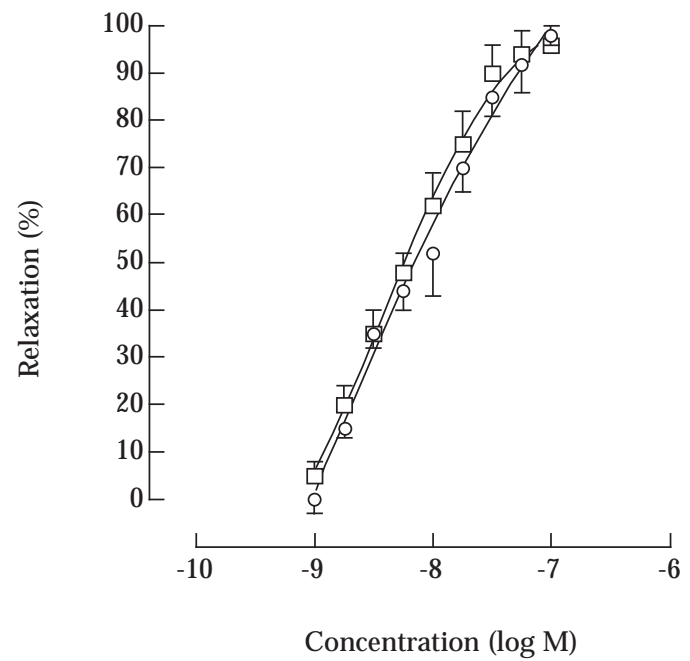

Figure 4. In vitro relaxant response to dopamine on ITA: dopamine alone $[\square]$; metoclopramide $\left(\mathbf{1 0}^{-6} \mathrm{M}\right)[\mathrm{O}]$.

outcomes of patency than saphenous vein..$^{[5-7]}$ As well, atherosclerosis is seen as delayed in ITA to native coronary artery. ${ }^{[8]}$ On the other hand, it has small caliber and sensitivity to vasospasm. ${ }^{[9]}$ Latter is important problem in perioperative period.Vasospasm is one of the most important factors that cause graft failure and morbidity in undergoing coronary artery bypass $(10,2)$. Injury of graft during harvesting and implantation stages may disturb the vasodilation mechanism in perioperative period. Following the vasospasm, blood flow in ITA is markedly decreased, and it may cause hemodynamic

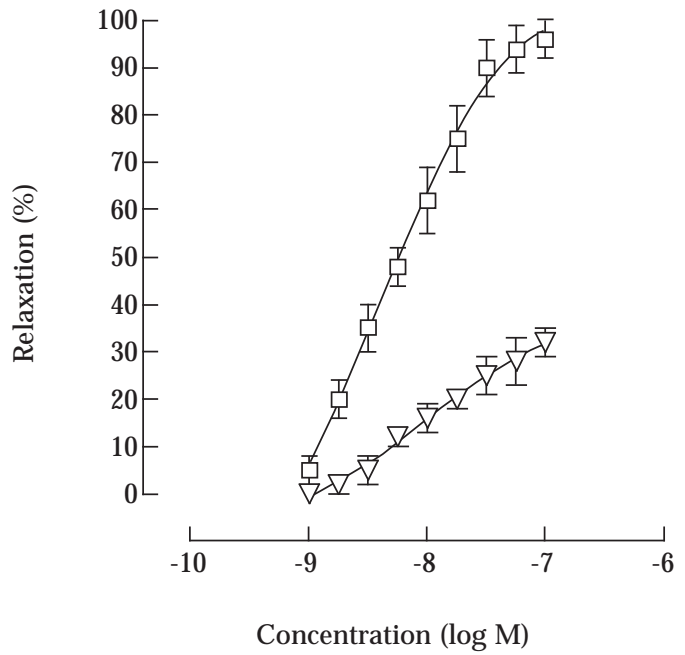

Figure 5. In vitro relaxant response to dopamine on ITA: dopamine alone $[\square]$; cis $\alpha$ flupenthixol $\left.\left(10^{-6} M\right)[\nabla]\right)$.

problems, ${ }^{[10]}$ which are related perioperative morbidity, postoperative myocardial failure and death. ${ }^{[11,12]}$ Furthermore, vasospasm of graft can affect early and late graft patency, ${ }^{[3,12]}$ and it may cause perioperative morbidity and mortality in patient with coronary artery bypass operation. ${ }^{[13]}$

He et al. ${ }^{[14]}$ reported in an in-vitro study that endothelium denuded ITA preparations show more vasoconstrictor response to noradrenaline than ITA preparations with intact endothelium. Besides, Chardigny et al. ${ }^{[15]}$ reported similar results to $\mathrm{He}$ et al. that vasoconstric- 


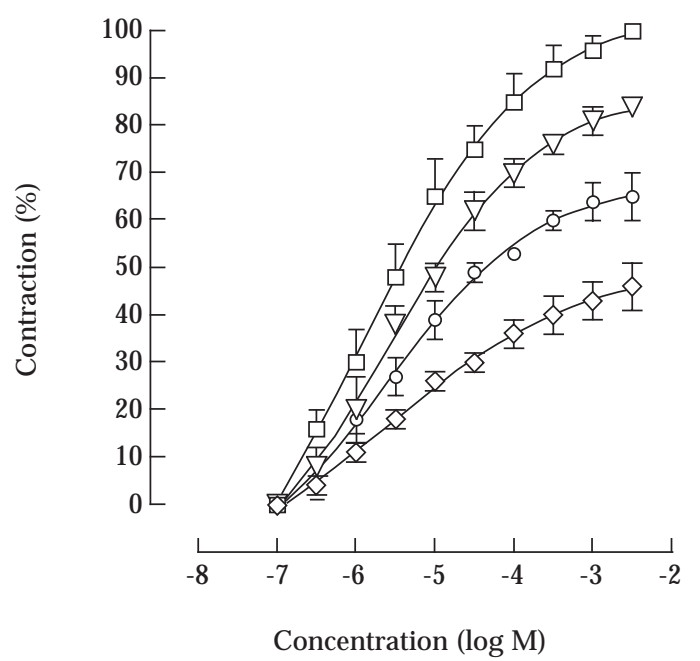

Figure 6. In vitro constrictor response to dopamine on ITA: dopamin alone $[\square]$; with phentolamine $\left(\mathbf{1 0}^{-8} \mathrm{M}\right)[\nabla]$, $\left.\left(10^{-7} M\right)[O],\left(10^{-6} M\right)[\diamond]\right)$.

tor response to noradrenaline in ITA is augmented by endothelial injury. Lüscher et al. ${ }^{[16]}$ detected that acetylcholine causes endothelium-related vasodilation on ITA preparations. In our study, vasodilator effect of low dose dopamine was decreased after adding L-NAME to organ bath, or after adding non-specific dopaminergic-receptor antagonist cis- $\alpha$-flupenthixol (but not $\mathrm{D}_{2}$-selective antagonis metoclopramide), or after adding non-specific $\beta$-adrenergic receptor blocker (propranolol). Based on the observation the fact that non-specific dopaminergic antagonist has some antagonistic effect on vasodilator response to dopamine on ITA, but $\mathrm{D}_{2}$-specific antagonist has not such effect, it can be speculated that $D_{1}$-receptors may mediate relaxant effect of dopamine. As a result, these findings indicate that both a $\beta$-adrenergic and a nitric oxide mediated mechanism (via $D_{1}$-dopaminergic receptor) may play a role in the relaxant effect of dopamine on ITA. Radioligand binding and light microscopy techniques showed the existence of $D_{1}$ and $D_{2}$ receptors on the rabbit pulmonary artery ${ }^{[17]}$ and only $\mathrm{D}_{1}$ receptors rat renal artery. ${ }^{[18]}$ As well, Mori et al. ${ }^{[19]}$ have been observed $D_{1}$ related vasodilation on rabbit pulmonary artery, which is reduced by cis- $\alpha$ flupenthixol (nonselective $D_{1}$ receptor blocker) in an organ bath study. It was suggested that vascular effects of dopamine are produced by specific dopamine receptors in cardiovascular system. ${ }^{[20,21]}$ Available data showed that activation of $D_{1}$ receptors (which are located on vascular smooth muscle postsynaptically) cause vasodilation and stimulation of $\mathrm{D}_{2}$ receptors (which are located on vascular smooth muscle presynaptically) cause inhibition of vasoconstriction. ${ }^{[5,21]}$ It has been reported that dopamine related vasodilation in human cardiovascular system is primarily

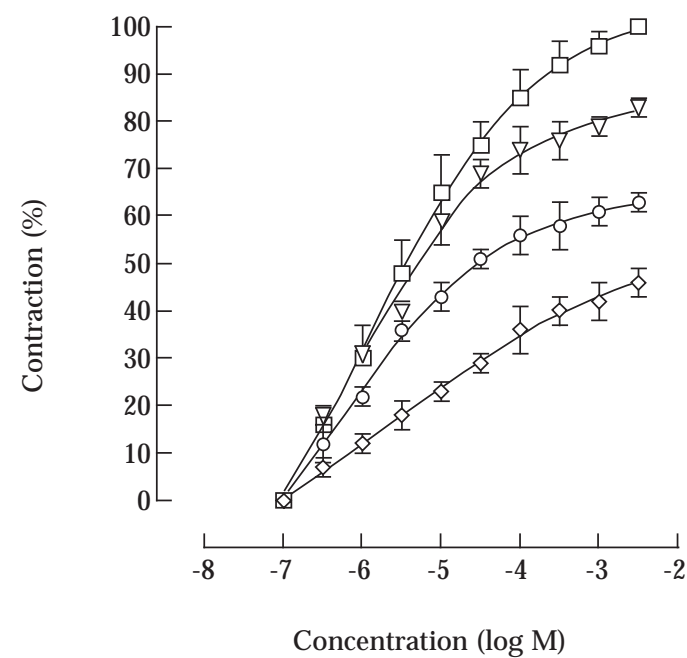

Figure 7. In vitro constrictor response to dopamine on ITA: dopamin alone [ $\square]$; with yohimbin $\left(10^{-6} \mathrm{M}\right)[\mathrm{O}]$; with prazosin $\left(10^{-6} \mathrm{M}\right)[\nabla]$; with yohimbin $\left(10^{-6} \mathrm{M}\right)+$ pra$z o \sin 10^{-6} M[\diamond]$.

mediated by $\mathrm{D}_{1}$ receptors. ${ }^{[22]}$ As well, $\mathrm{D}_{1}$ receptors have been detected in human renal, mesenteric, cerebral blood vessels, and it has been reported that these receptors subserve vasodilation. ${ }^{[23]}$ Yamuchi et al. ${ }^{[24]}$ reported that lowdose dopamine induces vasodilation via $D_{1}$ receptors, but high-dose dopamine produces vasoconstriction, and isoproterenol causes a weak dose-related vasodilation in human pulmonary artery. $\mathrm{D}_{1}$ receptors had also been detected in rabbit pulmonary artery. ${ }^{[19]}$ Katai et al. ${ }^{[25]}$ have been reported that $\mathrm{SCH} 23390$, a $\mathrm{DA}_{1}$ receptor antagonist, decreased dopamine related vasodilation on ITA in an in-vitro study. In addition to, there are some studies reported that dopamine causes vasoconstriction on ITA. ${ }^{[26,27]}$ Like our study, Forster et al. ${ }^{[28]}$ showed that dopamine related vasodilation of human basilar artery was decreased by cis- $\alpha$-flupenthixol. Also, sulpirid (selective $\mathrm{D}_{2}$ receptor antagonist) had no effect on relaxant response of ITA. It was reported that $\alpha$ - ve $\beta$-adrenergic receptors exist in human ITA. ${ }^{[29]} \beta$-adrenoreceptors have little role on ITA and thus, usage of $\beta$-blockers did not cause important vasospasm. ${ }^{[30]}$ Rosenfeldt et al. ${ }^{[30]}$ have found that isoproterenol, $\beta_{1}$ - and $\beta_{2}$-adrenoreceptor agonist, related maximum vasodilation is about $24 \%$. In another study with human ITA, which was precontracted with $\mathrm{KCl}$, isoproteronol produced a relaxant response about $13 \%$ of $\mathrm{KCl}$ contraction, and it was fully antagonized by propranolol. ${ }^{[31]}$

It was known that while $\alpha$ adrenoreceptors play a role in vasoconstriction, $\beta$ adrenoreceptors play a role in vasodilation. There were some studies showing $\alpha$ adrenergic receptor agonists such as noradrenaline, methoxamine, phenylephrine cause vasoconstriction in ITA. ${ }^{[32-34]}$ 
Also, $\alpha_{1}$ receptors are more prominent in ITA than $\alpha_{2}$ receptors. ${ }^{[30,31,35]}$ But He et al. ${ }^{[35]}$ have found that methoxamine (MO) and norepinephrine (NE) causes vasoconstriction on ITA, and the contractions induced by both $\mathrm{MO}$ and NE were totally abolished by $\alpha_{1}$-antagonist prazosin but not $\alpha_{2}$-antagonist yohimbine. As a result, they offered that in the human ITA the postjunctional $\alpha$-adrenoceptors are predominantly of the $\alpha_{1}$-subtype. In the another study, Katai et al. ${ }^{[24]}$ showed that dopamine produces vasoconstriction in the concentrations higher than $0.1 \mathrm{mM}$. In our study, ITA vasoconstriction with dopamine doses higher than $0.1 \mathrm{mM}$ was seen, and $\alpha 1$ and $\alpha 2$ receptor blockers decreased this response. Our data indicates that this vasoconstriction response may be mediated by stimulation of $\alpha_{1}$ and $\alpha_{2}$ receptors with dopamine.It was known that low $(0-3 \mu \mathrm{g} / \mathrm{kg} /$ min), middle (3-5 $\mu \mathrm{g} / \mathrm{kg} / \mathrm{min})$, and high $(10 \mu \mathrm{g} / \mathrm{kg} /$ $\mathrm{min}$ ) doses of dopamine infusions predominantly affect dopamine receptors, $ß$-receptors, $\alpha$-adrenergic receptors, respectively, on ITA graft. Thus, stimulation of these receptors determines the response of ITA to dopamine. $[19,24,36]$ Dopamine produces a vasodilator response at the lower concentrations and therefore, dopamine is used commonly as renoprotective agent. However, Türkay et al. reported that dopamine given at renal doses dose not protect renal tubular function in patients with normal heart and kidney functions undergoing coronary surgery and they do not recommend the use of dopamine for routine renal prophlaxis in this patients. ${ }^{[37]}$ In another study, it is reported that if low flow in ITA was detected during the operation, this graft tends to occlussion in in long period. ${ }^{[38]}$ As well, like other arterial grafts, any agent, which causes vasospasm on ITA, causes significantly decrease in graft flow. ${ }^{[39]}$ This condition may induce perioperative morbidity and mortality. ${ }^{[13]}$

In conclusion, it was found that dopamine produces a vasodilator response at the lower concentrations, whereas at the higher concentrations it causes a constrictor effect on ITA. Both a $\beta$-adrenergic and a nitric oxide mediated mechanism (via $\mathrm{D}_{1}$-dopaminergic receptor) may play a role in the relaxant effect of dopamine on ITA at the lower concentrations. Constrictor response to dopamine at the higher concentrations on ITA may be produced by the activation of $\alpha_{1}$ - and $\alpha_{2}$-adrenergic receptors.

\section{Conflict of Interest}

No conflict of interest declared by the authors.

\section{REFERENCES}

1. Woo Y, Gardner TJ. Myocardial Revascularization with Cardiopulmonary Bypass.In; Cardiac surgery in the adult. Cohn L.H, Edmunds L.H.(edts). Second edition. New York; McGraw-Hill; 2003;21:581-607.

2. Holm P, Franco Cereceda A. Tissue concentrations of endothelins and functional effects of endothelin- receptor activation in human arteries and veins. J Thorac Cardiovasc Surg 1996;112: 264-72.
3. Sellke FW, Boyle EM, Verrier ED. Endothelial cell injury in cardiovascular surgery: The pathophysiology of vasomotor dysfunction. Ann Thorac Surg 1996;62:1222-8.

4. Gaudino M, Toesca A, Maggiano N, Pragliola C, Possati G. Localization of nitric oxide synthase type III in the internal thoracic and radial arteries and the great saphenous vein: A comparative immunohistochemical study. J Thorac Cardiovasc Surg 2003;125:1510-5.

5. He GW. Contractility of the human internal mammary artery at the distal section increases toward the end. J Thorac Cardiovasc Surg 1993;106:406-11.

6. Sala A, Rona P, Pompilio G, Parolari A, Antona C, Biglioli $\mathrm{P}$, et al. Prostacyclin production by different human grafts employed in coronary operations. Ann Thorac Surg 1994;57:1447-50.

7. Wei W, Floten HS, He GW. Interaction between vasodilators and vasopressin in internal mammary artery and clinical significance. Ann Thorac Surg 2002;73:516-22.

8. He GW, Rosenfeldt FL, Buxton BF, Angus JA. Reactivity of human isolated internal mammary artery to constrictor and dilator agents. Implications for treatments of internal mammary artery spasm. Circulation 1989;80:141-50

9. Lin PJ, Chang C-H, Pearson PJ, Tzen K-Y, Chu J-J, Chang J-P, et al. Thromboxane A2: An Endothelium -derived vasoconstrictor in human internal mammary arteries. Ann Thorac Surg 1993;56:97-100.

10. Wackenfors A, Ingemansson R, Malmsjö M. Endothelin receptors in endothelium-denuded human coronary artery bypass grafts and coronary arteries. Ann Thorac Surg 2003;75:874-81.

11. He GW, Buxton BF, Rosenfeldt FL, Angus JA, Tatoulis J. Pharmacologic dilatation of the internal mammary artery during coronary bypass grafting. J Thoracic and Cardiovas Surg 1994;107;1440-4.

12. Blake KL, Watt PAC, Smith JMT, De Souza AC, Spyt TJ, Thurston H. Randomized comparison of ultrasonic aspiration versus conventional electrocautery for dissection of the human internal thoracic artery. J Thorac Cardiovasc Surg 1996;111:1194-9.

13. Flynn MJ, Winters D, Bren P, O'Sullivan G, O'Connel D, $\mathrm{O}^{\prime}$ Donnell A, et al. Dopexamine increases internal mammary artery blood following coronary artery bypass grafting. Eur J Cardiothorac Surg 2003;24:547-51.

14. He GW, Yang C-Q, Star A. Overwiew of the nature of vasoconstriction in arterial grafts for coronary operations. Ann Thorac Surg 1995;59:676-83.

15. Chardigny C, Jebara VA, Acar C, Descombes JJ, Verbeuren TJ, Carpentier A, et al. Vasoreactivitity of the radial artery comparison with the internal mammary and gastroepiploic arteries with implications for coronary artery surgery. Circulation 1993;88:115-27.

16. Lüscher TF, Diederich D, Siebenmann R, Lehmann K, Stulz $\mathrm{P}$, Segesser LV, et al. Difference between endotheliumdependent relaxation in arterial and in venous coronary bypass grafts. N Engl J Med 1988;319:462-7.

17. Kobayashi Y, Cavallotti D, Ricci AA. Localization of D2- like receptors in pulmonary artery of the human and rabbit but not of the rat. Eur J Pharmacol 1994;261:229-36.

18. Amenta F. Light microscope autoradiography of peripheral dopamine receptor subtypes. Clin Exp Hypertens 1997;19:27-41. 
19. Mori M, Hoshino Y, Obara H, Iwai S. Maturation-related changes in dopamine- induced relaxation of isolated rabbit pulmonary artery. Pediatr Res 1998;24:160-5.

20. Lokhandwala MF. Cardiovascular and renal effects of dopamine receptor agonists. ISA Atlas Science: Pharmacol 1998;261-6.

21. Lokhandwala MF, Hedge SS. Cardiovascular pharmacology of dopamine receptor agonists. In Peripheral dopamine pathophysiology, By F Amenta (Ed). First edition. Boca Raton: CRC Pres; 1990;63-77.

22. Hughes A, Inkpen $P$, Sever P. Action of dopamine on isolated human saphenous veins. J Cardiovas Pharmacol 1998;11:373-7.

23. Goldberg LI, Rajfer SI. Dopamine receptors: applications in clinical cardiology. Circulation 1985;72:245-8.

24. Yamuchi M, Kobayashi Y, Hattori K, Yamada K, Nakase A. Dopamine- induced relaxation in pulmonary arteries. Experienta 1989;45:150-2.

25. Katai R, Tsuneyoshi I, Hamasaki J, Onomoto M, Suehiro $\mathrm{S}$, Sakat $\mathrm{R}$, et al. The variable effects of dopamine among human isolated arteries commonly used for coronary bypass grafts. Anesth Analg 2004;98:915-20.

26. O’Neil GS, Chester AH, Schyns CJ, Tadjkarimi ST, Pepper $\mathrm{JR}$, Yacoub MH, et al: Vascular reactivity of human internal mammary and gastroepiploic arteries. Ann Thorac Surg 1991;52:1310-4.

27. Myers ML, Li GH, Yaghi, NcCormack D. Human internal thoracic artery reactivity to dopaminergic agents. Circulation 1993;88:110-4.

28. Forster C, Drew GM, Hilditch A, Whalley ET. Dopamine receptors in human basilar arteries. Eur J Pharmacol 1983;87:227-35

29. He GW. Arterial grafts for coronary artery bypass grafting: Biological characteristics, functional classification, and clinical choice. Ann Thorac Surg 1999;67:277-84.
30. Rosenfeldt FL, He GW, Buxton BF, Angus JA. Pharmacology of coronary artery bypass grafts. Ann Thorac Surg 1999;67:878-88.

31. Amenta F, Barili P, Bronzetti E, Felici L, Mignini F, Ricci A. Localization of dopamine receptor subtypes in sistemic arteries. Clin Exp Hypertens 2000;22:277-88.

32. He GW. Contractility of the human internal mammary artery at the distal section increases toward the end. J Thorac Cardiovasc Surg 1993:106:406-11.

33. He GW, Ryan WH, Acuff TE, Yang C-Q, Mack MJ. Greater contractility of internal mammary artery bifurcation: possible cause of low patency rates: Ann Thorac Surg 1994;58:529-32.

34. Weinstein JS, Grossman W, Weintraub RM, Thurer RL, Johnson RG, and Morgan KG. Differences in alpha-adrenergic responsiveness between human internal mammary arteries and saphenous veins. Circulation 1989;79:1264-70.

35. He GW, Shaw J, Hughes CF, Yang CQ, Thomson DS, McCaughan B, et al. Predominant $\alpha_{1-}$ adreneceptor mediated contraction in the human internal mammary artery. J Cardiovasc Pharmacol 1993;21:56-63.

36. Goldberg LI, Rajfer SI. The role of adrenergic and dopamine receptors. Hospital Pract 1985;20:67-80.

37. Turkay C, Golbasi I, Ak I, Sahin N, Korgun K, Erbasan O, et al. The effect of renal dose dopamine use on renal tubular function following coronary bypass surgery. Turkish J Thorac and Cardiovas Surg 2000;8:674-7.

38. Girard DS, Sutton III JP, Williams TH, Crumbley III AJ, Zellner JL, Kratz JM, et al. Papaverine delivery to the internal mammary artery pedicle effectively treats spasm. Ann Thorac Surg 2004;78:1295-8.

39. He GW, Yang CQ, Starr A. Overview of the nature of vasoconstriction in arterial grafts for coronary operations. Ann Thorac Surg 1995;59:676-83. 